\title{
SCHOOL POLICY IN RELATION TO SMOKING AND POSSIBILITIES FOR PREVENTION
}

\author{
Yustiniyanova B., M. Koleva \\ Department of medical and biological sciences, Medical University - Varna, Bulgaria
}

Reviewed by: Assoc. Prof. S. Popova

\begin{abstract}
Smoking is a prevalent health risk behaviour factor for the adolescents. Two hundred and sixty students were interviewed $-50,6 \%$ boys and $49,4 \%$ girls, aged 13-15 years. The survey was conducted in 2007 with a self-administered anonymous questionnaire that was used by the Global Youth Tobacco Survey (GYTS). The actual school policy in relation to smoking is ineffective according to the students interviewed. On account of the early age of initiation of smoking - 52,1\% of the students have started smoking at the age of 12-13 years - the prevention in primary school age is one of the most significant factors for the limitation of smoking and its injurious to health consequences. The authors have proposed a modulus exemplary programme for prevention of smoking at schools.
\end{abstract}

Key words: smoking, adolescents, school policy, prevention programme

\section{INTRODUCTION}

According to the data of the national Statistical Institute, Bulgaria continues to be in the third place in the world in use of cigarettes per person as the age of initiation of smoking decreases and the prevalence of smoking among adolescents increases. The frequency of smoking among boys and girls in Bulgaria aged 15 years is one of the highest in Europe according to the international survey ESPAD (1). The results of the Global Youth Tobacco Survey (GYTS, 2002), conducted in 142 countries under the surveillance of the World Health Organization (WHO), the Centers for Disease Control and Prevention in Atlanta and UNICEF, show that the Bulgarian students are among the first in the world in early tries of smoking cigarettes and intensity of smoking. The prevalence of smoking among girls aged 13-15 years is the highest in 76 countries where GYTS was performed as national surveys until 2003.

The data is an evidence that smoking in Bulgaria is a prevalent health risk behaviour factor $(2,3)$.

The school has a significant role as an environment for endorsement of healthy behaviour not only by active informing and education of the students about the advantages of a healthy lifestyle but also as an environment for the formation of values, attitudes, abilities and behaviour competence of healthy choice, including decision-making about initiation of smoking. The school environment, in this regard, is one of the main determinants of smoking among students (4).

Address for correspondence:

B. Yustiniyanova, Dept. of medical and biological sciences, Medical University, 55 Marin Drinov str., 9002 Varna, Bulgaria

e-mail: bisera_23@abv.bg
Evaluating the health and social significance as well as the immediacy of the problem, we set our aim: to study the school policy concerning smoking among students with a view to its prevention at school.

\section{MATERIAL AND METHODS}

Two hundred and sixty students aged 13-15 years were interviewed (50,6\% boys and $49,4 \%$ girls) in three schools in Ruse. This age group is defined by the experts of the World Health Organization as a risk group because smoking usually starts at the age of 12 or 13 years. This is the period of transition from primary to secondary education when the students must overcome new educational, psychological and social challenges.

The survey was conducted in 2007 with a self-administered anonymous questionnaire which consists of 60 questions concerning various aspects of the problem of smoking. The self-administered questionnaire that was used gives unique information because smoking among adolescents was studied in a different way and what is especially current now; the questionnaire gives possibility for comparison of the received results with those of the countries that participated in GYTS.

The alternative analysis was used for the data processing.

\section{RESULTS AND DISCUSSION}

The school policy concerning smoking is represented in fig.1.

According to $47,2 \%$ of the students interviewed, the topic of the injurious to health effect of smoking was discussed at 
school. For $23,3 \%$ of the students interviewed there had been no discussion of this problem at school.

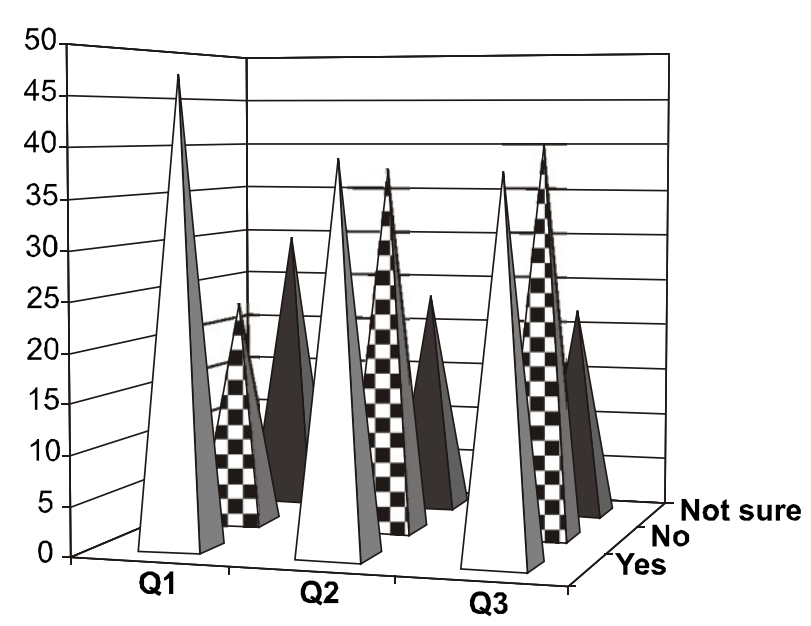

Fig.1 The school policy concerning smoking (Q1-Has the harmfulness of smoking been discussed in some of the school periods? Q2-Has the medical specialist explained why smoking is harmful? Q3-Has it been discussed why young people smoke?)

One in three students was not sure that an actual policy against smoking was pursued in their school.

An alarming fact is that according to $61 \%$ of the students interviewed the medical specialist at school had not explained why smoking cigarettes is injurious to health. Only $37,7 \%$ of the students reported that they had discussed the topic "why young people smoke" in the class teacher period.

To the question: "When was the last time that the problems concerning smoking and its harmful consequences were discussed during a lesson at school?", the students had answered the following:

$$
\begin{aligned}
& \text { - } \mathrm{Never}-39,4 \% \\
& \text { - } \mathrm{This} \text { term - } 14,8 \% \\
& \text { - } \text { Last term - } 21,3 \% \\
& \text { - } \text { Two terms ago - } 7,1 \% \\
& \text { - } \text { Three terms ago - } 2,6 \% \\
& \text { - } \text { More than a year ago - } 14,8 \%
\end{aligned}
$$

According to an inquiry survey for the spread of active smoking among the school personnel, $53,7 \%$ of the principals and $44,5 \%$ of the teachers smoke at school, as $1 / 3$ of them are ever smokers. Seventy two percent of the principals and fifty eight percent of the teachers who smoke are not inclined to give advice on prevention of smoking.

Our results correspond with those of other authors that participated in the Global School Personnel Survey (GYPS) (7). The received results show that the school policy in relation to prevention of smoking and its injurious to health effect on the adolescents is not effective enough. An evidence of this are our data for prevalence and intensity of smoking according to which $52,1 \%$ of the students interviewed had started smoking at the age of 12-13 years (Fig.2).

Ever smokers are $46,2 \%$ of the boys and $35,3 \%$ of the girls as 1 in 4 students interviewed reported that they smoked most intensively at school which presumes that there is not enough control of the principals, teachers and medical specialists.

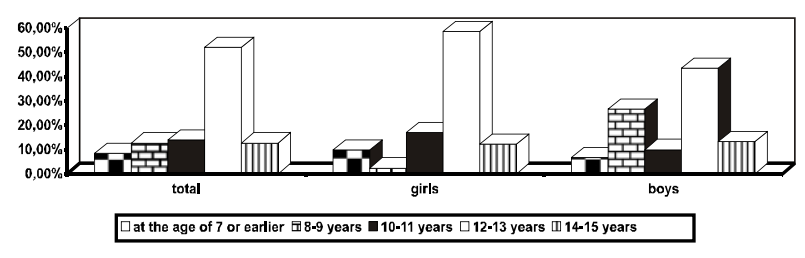

Fig.2 Primary age of initiation of smoking

Intensive smokers (smoke over 6 cigarettes a day) are 31\% of the boys and $47 \%$ of the girls. Excessive smokers, who smoke more than 20 cigarettes a day, were found only among girls - 15,4\%.

The results of the GYTS, implemented in Greece, show that ever smokers are $32,1 \%$ of the students aged 13-15 years of whom $34,6 \%$ boys and $28,9 \%$ girls. Before the age of 10 cigarettes had started smoking $25,5 \%$ of the boys and $21,4 \%$ of the girls (5). A similar survey is conducted by other authors (6).

The school environment has a significant influence over the attitudes and convictions related to tobacco use. One in five of the students interviewed reported that the students who smoke at school have more friends. The fact that smoking as a risky behaviour fulfils a social function (search of identity, gaining the trust of peers and friends, opposition to the authority of adults) is one of the reasons why it is difficult to take preventive measures and that they rarely give a result, having in mind that young people live in the present and they don't think about the distant health consequences of smoking.

\section{CONCLUSION}

1. The actual school policy in relation to smoking is ineffective.

2. On account of the early age of initiation of smokingamong the students which is $12-13$ years, prevention in primary school age is one of the most significant factors for limitation of smoking and its injurious to health consequences.

3. On the basis of the results of the complete survey we worked out an Exemplary programme for prevention and control of smoking at school.

\section{Exemplary programme for prevention and control of smoking at school}

The programme that I propose is based on the health promotion models of Poland and Green (2000) who examine four kinds of health promotion models in primary and secondary school age:

- models, based on knowledge - basic level in the prevention of smoking which gives the basis for development of the next models 
- effective training models - they deal mainly with the development of the students' personality. These include training methods for building up self-confidence, development of personal skills, making decisions and skills for coping with the problem of smoking

- behavioural models - they include mainly training methods and tactics for students' resistance to the pressure of the social environment (friends who smoke, advertisements, etc.) for involvement in hazardous to health behaviour such as smoking.

- model for students' authorization - the main principle used in this model is that the students should be responsible to identify and define the problem alone and to determine what action to take in relation to prevention of smoking.

In the exemplary programme that is worked out, particular measures for prevention of smoking have been proposed to every one of the presented models, conformed to the age of the students from primary and secondary school.

\section{REFERENCES}

1. Колева, М. Здравно-социални аспекти и възможности за превенция на тютюнопушенето в училищна възраст. Дипломна работа, 2007, Варна.

2. Попов, Г. Дроги и превенщия. Стено, 2000, Варна.

3. Цолова, Г., Петрова, К., Маринова, П. Тютюнопушенето - рисков фактор за здравето на децата. Социална медииина, 2006, 1-2, $42-43$.

4. Юстиниянова, Б., Колева, М. Разпространение и детерминанти на тютюнопушенето при ученици. Trakia $J$. of sciences, vol. 6, 2, suppl. 3, 2008, 9-12.

5. Kyrlesi, A., E. S. Soteriades, Ch. W. Warren, J. Kremastinou et al. Tobacco use among students aged 13-15 years in Greece: the GYTS project. BMC Public health, 2007, 7:3.

6. Rozi S., S. Akhtar. Smoking among high school adolescents in Karachi, Pakistan. Int. J. Epidemiol,

June 1, 2004; 33 (3): 613-614.

7. Sinha, D. N., P.C. Gupta, M.S. Pednekar, J. $\mathrm{T}$. Jones et al. Tobacco use among school personnel in Bihar, India. Tobacco control, 2002, 11 (1): 82-83. 